\title{
A Comparative Study of Antimicrobial and Pharmacological Properties of Argemone mexicana, Solanum xanthocarpum and Thevetia peruviana
}

\section{Jyotsna Jaiswal and Bechan Sharma*}

Department of Biochemistry, Faculty of Science, University of Allahabad, India

*Corresponding Author: Bechan Sharma, Department of Biochemistry, Faculty of Science, University of Allahabad, India.

DOI: 10.31080/ASMI.2020.03.0524
Received: January 17, 2020

Published: February 14, 2020

(C) All rights are reserved by Jyotsna Jaiswal

and Bechan Sharma.

\begin{abstract}
Extracts obtained from different parts of the plants are reported to exhibit therapeutic potential due to presence of different phytochemical compounds. The extracts plant leaves, stem, seeds, flowers, fruits and roots of so many medicinal plants and weeds have been found to contain antibacterial and therapeutic potential. However, not much work has been conducted with the extracts of Argemone mexicana, Solanum xanthocarpum and Thevetia peruviana. This article presents a recent account of preparation of extracts from different parts of these plants, their chemical and biochemical characterization and future perspectives.

Keywords: Argemone mexicana; Solanum xanthocarpum; Thevetia peruviana
\end{abstract}

\section{Introduction}

Therapeutic potential of medicinal plants have proved to be a boon to mankind. The medicinal plants are known to contain different pharmacological properties. In addition many wild and ornamental plant species have been found to offer protection of humans from variety of ailments and diseases [1-3]. The increased resistance of microorganism may be associated with unrestricted use of antimicrobial substance or antibiotics. With the current trend of rise in resistance in microorganism towards many antibiotics, the treatment of several diseases by using antibiotics is posing challenge to chemotherapy. Thus, there is an urgent need of some novel drugs to cure various microbial infections and diseases. It prompted the workers to explore new plant based molecules as modern antimicrobial substances which may prove to be safe, cost effective and efficient regimen [3-5].

Some weeds are known to have toxicants. Such weeds might be using these toxic chemicals in order to protect themselves from other living beings. Some of these plants contain certain phytochemicals which act as therapeutic agents. These compounds posses significant antimicrobial properties and immense potential to cure deadly diseases [6].

Different parts of the plants such as leaves, stem, seeds, flowers, fruits and roots of so many medicinal plants and weeds have been reported to have antibacterial potential from last two decades. The extracts from these parts of the plants have been shown to contain major phytoconstituents such as Alkaloids, glycosides, flavonoids, sterols, tannins and luxuriant antibacterial compounds $[7,8]$.

Argemone mexicana L. (Papaveraceae), is mainly found in Mexico but now it is widely distributed in many parts of the world including India, Bangladesh, United States and Ethiopia. It is a species of poppy [8] and commonly known as Prickly Poppy in English and "pili kateri" in Hindi (Figure 1). Some workers have reported that leaves and seeds of $A$. mexicana have significant antimicrobial activity. The essential oil of A. mexicana is also found active against some microbial species [9].

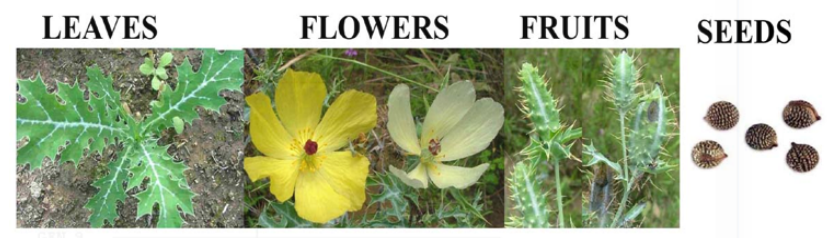

Figure 1: The leaves, flowers, fruits and seeds of A. mexicana.

The plant, Solanum xanthocarpum, belonging to the family Solanaceae, is commonly known as yellow Berried Night Shade or Indian night shade plant. Another synonym to it is Kantakari (Figure 2). It is used for various medicinal purposes in many regional areas. The plant is known to contain chemical ingredients of medicinal significance. The leaves, stem, flowers, fruits and roots of the plant are used in Aurvedic medicines. It contains several phytochemicals such as alkaloids, flavonoids, phenolics, flavonoids, tannins, carbohydrates, glycosides and saponins in plenty in addition to some essential amino acids and fatty acids. "Dasmula Ashva" is prepared by roots of $S$. xanthocarpum $[10,11]$. The extracts of $S$. xanthocarpum exhibited antioxidant, antifertility, anticancer, antipyretic, antifungal, antibactreial antiallergic, anti-inflammatory, antihistamine, and hypoglycemic properties [11]. 


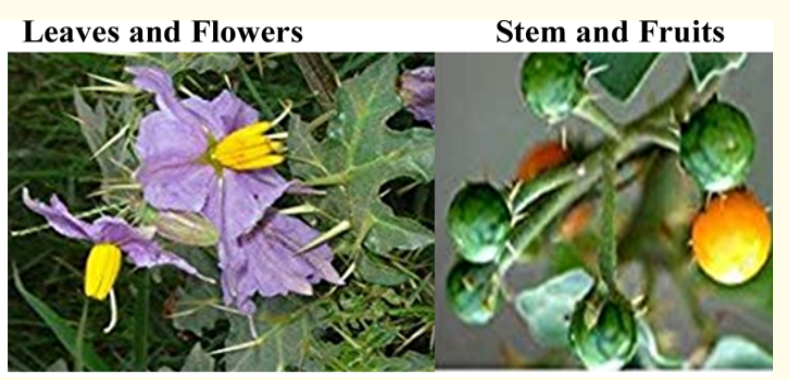

Figure 2: The leaves, flowers, stem and fruits of $S$. xanthocarpum (Kantkari).

The plant, Thevetia peruviana, belongs to the family Apocynaceae, commonly known as Yellow oleander and Lucky nut. Several species of this plant are found world-wide, mostly in India, Australia, and China. It is a shrub grown for ornamental and medicinal purposes (Figure 3).

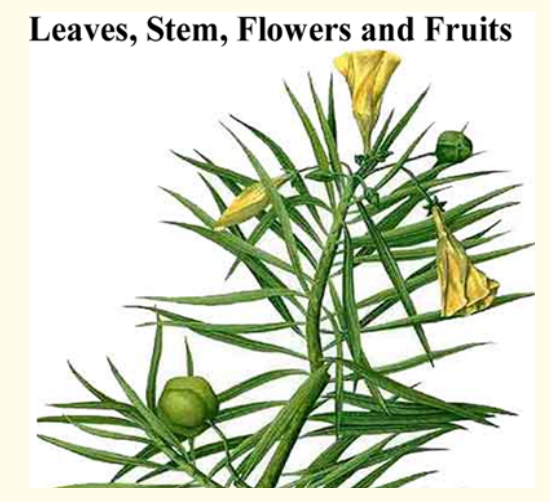

Figure 3: The leaves, stem, flowers and fruits of T. peruviana.

The extracts of stem and bark of the plant have been reported to antipyretic properties. The leaves of this plant contain Flavanones and Flavanol glycosides which are used as antimicrobial agents especially against Cladosporium cucumerinum. The extracts of leaves of this plant have also been found to possess antiHIV-1 RT and antiHIV-1 integrase properties. The extracts of its seeds are reported to exhibit genotoxic potential. In addition, the bioactive chemical ingredients isolated from T. peruvina may be used as fungicides, bactericides, insecticides and rodenticides [12].

\section{Materials and Methods}

The methodology involved in the preparation of the present manuscript associates collection of various review articles, research articles and case studies / reports from various sources such as Google Scholar, PubMed, ResearchGate and Semantic Scholar.

\section{Traditional perspectives of plants}

From the ancient times plants have been known for their potential of having antibiotic properties to treat microbial diseases involving bacterial, viral and fungal infections. The plant parts root, leaves, stem and flowers have been utilized by Indians as medicinal source. The presence of medicinal property is due to presence of secondary metabolites in plant. As per World Health Organization (WHO), a huge variety of drug can be obtained by medicinal plants $[2,3]$.

Argemone mexicana is traditionally used as hallucinogenic, analgesic antispasmodic, antimicrobial [13] and antitussive [8,14]. In snake poisoning seeds of $A$. mexicana have been used as an antidote [15]. The treatment of diuretic, leprosy, cold sores, wound healing, scorpion sting, warts skin diseases, itches, jaundice, malarial fever, anti-inflammatory is by the milky seed extracts because they are rich in protein-dissolving substances. It is also used as antidote to many poisons and smoke of the seed used in toothache [8]. Another Indian weed Solanum xanthocarpum is reported to have therapeutic potential due to presence of phytochemicals. leaves, stem, root, fruits and flowers are used many Ayurvedic preparations. "Dasmula Ashva" is prepared form roots of the plant $[10,11]$. Thevetia peruviana used as traditional medicine by so many practitioners because it contains a wide range of natural substances which are non-allergenic, nontoxic or selectively toxic to the host and do not exhibit any side effects [16]. In general, the medicinal plants could serve as a potential reservoir for the development of novel chemotherapeutic agents against various diseases.

Pharmacological chemistry of chemical ingredients from Argemone mexicana, Solanum xanthocarpum and Thevetia peruviana

The plants Argemone mexicana, Solanum xanthocarpum, and Thevetia peruviana are well known Indian weeds. They possess medicinal properties due to presence of phytochemicals in their roots, stem, leaves, fruits, and flowers. Major phytoconstituents found in different parts of these plants are berberine, allocryptopine, sanguinarine, saponins, solanacarpine, solamargine, caffeic acid, coumarins, aesculetin, aesculin, and thevetin [17].The pharmacological properties of some important phytochemicals are summarized in Table 1.

Antimicrobial properties of argemone mexicana, solanum xanthocarpum, and Thevetia peruviana

The extracts of $A$. mexicana showed wide spectrum of antimicrobial properties s observed through screening. On comparison of the antimicrobial activity of the extracts prepared from root, stem and leaves of $A$. mexicana in the solvents such as $\mathrm{H}_{2} \mathrm{O}$, acetone, ethanol and chloroform, the ethanolic extract of stem showed the 


\begin{tabular}{|c|c|c|c|c|}
\hline Plant name & Plant parts & Major constituents & Pharmacological properties & References \\
\hline \multirow[t]{3}{*}{ Argemone mexicana } & $\begin{array}{l}\text { Apigeal parts, } \\
\text { seeds }\end{array}$ & Berberine & $\begin{array}{l}\text { Anti-fertility activity } \\
\text { Effect on ileum contraction in guinea pig, } \\
\text { Antimalarial activity }\end{array}$ & {$[18,19,20,21,22]$} \\
\hline & Apigeal parts & Allocryptopine & $\begin{array}{c}\text { Effect on ileum in guinea pig } \\
\text { Antimalarial activity }\end{array}$ & {$[20,21]$} \\
\hline & Seeds & Sanguinarine & Mollucicidal activity & {$[23,21]$} \\
\hline \multirow[t]{2}{*}{ Solanum xanthocarpum } & Fruit & Saponins & Function in stimulation of Heart & {$[24]$} \\
\hline & Fruit & $\begin{array}{c}\text { Solanacarpine, sola- } \\
\text { margine, caffeic acid } \\
\text { coumarins, aesculetin } \\
\text { and aesculin }\end{array}$ & $\begin{array}{l}\text { Lowering of cholesterol, protection against } \\
\text { infection by Salmonella typimurium, anti-cancer } \\
\text { activity }\end{array}$ & {$[24]$} \\
\hline Thevetia peruviana & Seeds & Thevetin & Heart stimulant, blood pressure irreguation & {$[25]$} \\
\hline
\end{tabular}

Table 1: Pharmacological properties of some phytochemicals present in Argemone mexicana, Solanum xanthocarpum, and Thevetia peruviana.

highest potential as compared to acetone, aqueous and chloroform extracts. The ethanolic extract of $A$. mexicana stem was recorded with highest antimicrobial activity against $K$. pneumoniae followed by, S. aureus and E. coli. The authors demonstrated least inhibitory activity against $B$. cereus. In each of these experiments, a standard antibiotic, Ampicillin, was used as a positive control [8]. More et al. (2017) have reported that oil extracts of A. mexicana, exhibited significant inhibitory effects on the growth of filamentous and nonfilamentous fungus (C. albicans) along with a few bacterial species such as Bacillus subtilis, Klebsiella pneumoniae, Pseudomonas aeruginosa, and Staphylococcus aureus in concentration dependent manner. While using the agar well diffusion method, they have evaluated the antimicrobial activity of crude extracts prepared from the leaves, stem, seeds and roots of A. mexicana. These extracts were found to be active against different bacterial species belonging to both of the groups such as the Gram positive bacteria (Bacillus cerus, Bacillus subtilis, Clostridium perfringens, Enterobacter faecalie, botulinum Stapphyllococcus aureus, and Streptococcus agalactae,) and the Gram negative bacteria (E. coli, Klebsiella pneumoniae, Proteus mirabilis, Proteus vulgaris, Pseudomonas aeruginosa and Salmonella typhimurium) [22].

One of such studies carried out by Rana et al. (2016) have shown that the Solanum xanthocarpum leaf extracts prepared in solvents like methanol and acetone were possessing antibacterial properties; the methanolic extracts showing better antibacterial property than that of acetone extract (Table 1). However, the acetone extracts of $S$. xanthocarpum proved to be a better antibacterial agent against certain $S$. aureus species [11].

The aqueous, hydroethaolic and ethanolic extracts of $S$. xanthocarpum inhibited the growth of Gram negative bacterial species such as $S$. aureus and E. coli. The aqueous extracts of $S$. xanthocarpum exhibited mild to moderate inhibition over the growth of tested bacterial pathogens. The ethanolic extract was found to be having more potent anti-microbial activity than those of aqueous and hydro ethanolic extracts [26].

The extracts from different parts of the plant, Thevetia peruviana, have been found to effectively inhibit the growth of several microbial species. The results as presented by Gezahegn et al. (2015) showed minimum inhibitory concetrtion (MIC) of the plant extracts prepared in the different solvents. The extracts of leaves of T. peruviana preapared in acetone, chloroform, methanol and petroleum ether inhibited the growth of standard strains of E. coli, while the leaf extract of T. peruviana prepared in acetone, chloroform, methanol and petroleum inhibited the growth of $S$. aureus and S. typhimurium [27]. However, the antimicrobial activity of $T$. peruviana leaf extract prepared in ethanol is reported to exhibit with narrow zone of inhibition against Shigella flexineri,Salmonella typhi, Staphylococcous aureus and Shigella sonnei [25].

Recently, Deshmukh et al. (2019) have reported that the aqueous and ethanolic extracts of flowers of T. peruviana exhibited maximum antibacterial activity against $E$. coli with ethanol as compared to water. They have displayed similar trend of antimicrobial activity of ethanolic extracts of fruits of T. peruviana against E.coli [28].

\section{Conclusions}

As evident from above information, each of the three plant species display significant amount of antimicrobial properties. These plant species are widely distributed in India. However, extensive work is needed to explore the antimicrobial properties of different specific phytochemicals isolated from different parts of these plants to exploit their full medicinal potential.

\section{Acknowledgements}

BS is grateful to UPCST-Lucknow for financial support in the form of a research project grant. JJ thanks UPCST Lucknow for pro- 
viding a fellowship to conduct the research work of this project. Both the authors also thank DST-FIST and UGC-SAP for providing research facilities.

\section{Conflict of Interests}

Authors declare no any conflicts of interest.

\section{Bibliography}

1. Bhagwati U. "Utilization of medicinal plants by rural women of Kulu”. Indian Journal of Traditional Knowledge (2003): 366370.

2. Agrawal A and Sharma B. "Natural products and their antioxidant potential". Natural Products TSI Journals 8.2 (2012): 72-87.

3. Singh RK and Sharma B. "Certain Traditional Indian Plants and Their Therapeutic Applications: A Review". Vri Phytomedicine (2013): 1-11.

4. Karaman I., et al. "Antimicrobial activity of aqueous and methanol extracts of Juniperus oxycedrus L". Journal of Ethnopharmacology (2003): 231-235.

5. Sharma B. "Phytochemicals may arrest HIV-1 progression". Clinical Research in Hiv Aids and Prevention 1 (2013): 30-35.

6. Del Campo J., et al. "Antimicrobial effect of Rosemary extract". Journal of Food Protection (2000): 1359-1368.

7. Meera P., et al. "Antibacterial effects of selected medicinal plants on the bacteria isolated from Juices". Geobias (1999): 17-20.

8. Alagesaboopathi $\mathrm{C}$ and Kalaiselvi N. "Antimicrobial activities of the root, stem and leaf extracts of Argemone mexicana L". International Journal of Biosciences (IJB) (2012): 61-68.

9. Osho A and Adetunji T. "Antimicrobial activity of the essential oil of Argemone mexicana Linn)" (2010).

10. Amir M and Kumar S. "Possible industrial applications of genus Solanum in twenty first century- A review". Journal of Scientific and Industrial Research (2004): 116-124.

11. Rana S., et al. "Antibacterial Activity of Solanum xanthocarpum Leaf Extract". International Journal of Current Microbiology and Applied Sciences (2016): 323-328.

12. Sharma R., et al. "Antimicrobial properties of Thevetia peruviana". Rasayan Journal of Chemistry (2012): 403-505.

13. Ishizuka K., et al. "Inhibition of HIV-1 Reverse Transcriptase Activity by the Extracts of Indian Plants". International Journal of Biological Macromolecules (2020).
14. Jain NK and Sharma SN. "A text book of professional pharmacy". Vallabha Prakashan (2001): 266.

15. Bhattacharjee I., et al. "Antibacterial potential of Argemone mexicana solvent extracts against some pathogenic bacteria". Mem Inst Oswaldo Cruze Rio de Janeiro (2006): 645-648.

16. Ahmad T., et al. "Thevetia peruviana: a multipurpose medicinal plant- a review". International Journal of Advanced Research 5.8 (2017): 486-493.

17. Adhikari BS., et al. "Medicinal plants diversity and their conservation status in Wild Life Institute of India (WII) campus, Dehradun". Ethnobotanical Leaflets 14 (2010): 46-83.

18. Gupta RS., et al. "Antifertility studies of isoquioline alkaloids with special emphasis on structure activity relationship Fitoterapia". 61.1 (1990): 67-71.

19. Piacente S., et al. "Different effects of some isoquinoline alkaloids from Argemone mexicana on electrically induced contractions of isolated Guineapig Ileum". Phytotherapy Research (1998): 155-157.

20. Avello Simoes Pires C. "Investigation of antiplasmodial compounds from various plant extracts Thèse dedoctorat". The University of Geneva (2009): 4129.

21. Avello Simoes Pires C. "Investigation of antiplasmodial compounds from various plant extracts Thèse dedoctorat". The University of Geneva (2009): 4129.

22. Brahmachari G., et al. "Argemone mexicana: chemical and pharmacological aspects". Revista Brasileira de Farmacognosia-Brazilian Journal of Pharmacognosy 23.3 (2013).

23. Singh S and Singh DK. "Effect of mollucicidal components of Abrus precatorius, Argemone mexicana and Nerium indicum on certain biochemical parameters of Lymnaeu acuminate". Phytotherapy Research (1999): 210-213.

24. Parmar S., et al. "Solanum xanthocarpum (Yellow Berried Night Shade): A review". Sheth Der Pharmacia Lettre 2.4 (2010).

25. Singh K., et al. "A Review on: Thevitia peruviana”. International research Journal of Pharmacy 3.4 (2012).

26. Priya P., et al. "Anti-microbial, Anti-oxidant and Anthelmintic Activity of Crude Extract of Solanum xanthocarpum". Pharmacognosy Journal (2010): 2- 11.

27. Gezahegn Z., et al. "Antibacterial potential of Thevetia peruviana leaf extracts against food associated bacterial pathogens". Journal of Coastal Life Medicine (2015): 150-157. 
28. Deshmukh AS., et al. "Estimation of Antibacterial activity of Crude Extracts of Thevetia Peruviana". International Journal of Microbiology and Current Research 1.1 (2019): 1000104.

\section{Assets from publication with us}

- Prompt Acknowledgement after receiving the article

- Thorough Double blinded peer review

- Rapid Publication

- Issue of Publication Certificate

- High visibility of your Published work

Website: https://www.actascientific.com/

Submit Article: https://www.actascientific.com/submission.php Email us: editor@actascientific.com

Contact us: +919182824667 